Navigation Physics 2(1) (2020)
Navigation Physics
Journal of Physics Education

\title{
Penerapan Pembelajaran Berbasis Proyek dengan E-Learning untuk Meningkatkan Kreativitas dan Hasil Belajar Mahasiswa pada Mata Kuliah IPA Terpadu
}

\author{
Indica Yona Okyranida ${ }^{1}$ \\ ${ }^{1}$ Universitas Indraprasta PGRI \\ *E-mail: indicaoky@gmailcom
}

\begin{tabular}{ll}
\hline Info Artikel & Abstract \\
\hline $\begin{array}{l}\text { Sejarah Artikel: } \\
\text { Diterima April } 2020 \\
\text { Disetujui Mei } 2020 \\
\text { Dipublikasikan Juni } 2020\end{array}$ & $\begin{array}{l}\text { In this study aims to determine the influence of implementation of project- } \\
\text { based learning with e-learning to improve creativity and student learning } \\
\text { outcomes in the integrated SCIENCE course. The results of creativity data } \\
\text { obtained from the poll of creativity given to the students get the pretests } \\
\text { results got the lowest score of } 45 \text { and the posttest can be the lowest score of } \\
\text { Keywords: } \\
\text { 6uliskan kata kunci 3-5 kata } \\
\text { the highest score when the pretests obtained the results } 68 \text { and posttest } 80 \\
\text { and concluded there is a rise in the highest score. Average pretests results } \\
\text { obtained } 58 \text { and Posttest } 75 \text {, so learning using the project has a significant } \\
\text { influence on student creativity. Results of cognitive learning results derived } \\
\text { from the test problem given to students getting pretests results get the } \\
\text { lowest score of } 55 \text { and on the posttest can be the lowest score of } 70, \text { so that } \\
\text { there can be a score increase on the lowest score. At the highest score when } \\
\text { the pretests obtained the results } 75 \text { and Posttest } 87 \text { and concluded there is a } \\
\text { rise in the highest score. Average pretests results obtained } 63 \text { and Posttest } \\
\text { 79, so that learning using the project has a significant influence on student } \\
\text { learning outcomes. }\end{array}$ \\
\hline
\end{tabular}

How to Cite: Okyranida, I.Y. (2020). Penerapan Pembelajaran Berbasis Proyek dengan E-Learning untuk Meningkatkan Kreativitas dan Hasil Belajar Mahasiswa pada Mata Kuliah IPA Terpadu. Navigation Physics, 2 (1): 3640.

\section{PENDAHULUAN}

IPA Terpadu merupakan mata kuliah pilihan pada prodi pendidikan fisika yang diambil mahasiswa untuk meningkatkan kompetensi mereka dalam perkembangan pendidikan IPA. Mata kuliah ini disiapkan bagi mahasiswa untuk dapat mengkaji pembelajaran IPA yang terdiri dari fisika, kimia, dan biologi yang dibahas secara bersama. Pada mata kuliah IPA terpadu mahasiswa harus dapat membahas dan mengkaji materi sains menjadi satu permasalahan dan pembahasan yang akan diaplikasikan dalam kehidupan sehari-hari. Pengemasan pembelajaran IPA juga akan dikemas dalam bentuk produk berupa buku, modul, alat, ataupun media pembelajaran lainnya yang dapat meningkatkan motivasi belajar.

Pembelajaran terpadu membuat peserta didik terlatih untuk dapat memperoleh pengalaman langsung sehingga dapat menjadikan kekuatan untuk menerima, menyimpan, serta mengaplikasikan konsep yang telah diterima dalam proses pembelajaran (Trianto, 2014). Pada mata kuliah IPA terpadu terjadi kendala yang dialami mahasiswa ketika mengikuti perkuliahan. Sesuai dengan angket kebutuhan awal disimpulkan ada 4 faktor yang menyebabkannya yaitu, pertama mahasiswa kesulitan menggabungkan materi IPA terpadu menjadi satu permasalahan dan pembahasan, karena selama ini mahasiswa terbiasa hanya mengkaji satu ilmu yaitu fisika. Kedua, media pembelajaran yang digunakan dalam perkuliahan masih minim hanya menggunakan modul dari dosen. Ketiga, belum tersedianya laboratorium untuk praktikum IPA. Keempat, masih kurangnya kreativitas mahasiswa terhadap materi IPA terpadu. 
Model pembelajaran merupakan salah satu faktor yang dapat mempengaruhi kemampuan berpikir dan juga hasil belajar mahasiswa. Pembelajaran berbasis proyek merupakan pembelajaran yang dapat meningkatkan aspek kognitif dan juga ujuk kerja siswa (Hayati et al., 2013). Pembelajaran ini merupakan pengembangan dari pembelajaran kontekstual yang efektif karena berpotensi menajadikan pembelajaran bermakna dan meningkatkan kreativitas dan kerjasama tim sampai tercipta suatu proyek yang nyata (Na'imah et al., 2015). Pembelajaran berbasis proyek sangat cocok digunakan dalam pembelajaran IPA Terpadu yang dapat meningkatkan kreativitas dan juga hasil belajar mahasiswa. Dalam pembelajaran IPA, anak didik diharapkan menguasai standar kompetensi kajian ilmiah yang meliputi: (1) penyelidikan, (2) berkomunikasi ilmiah, (3) pengembangan kreativitas dan pemecahan masalah, dan (4) sikap dan nilai ilmiah. Kompetensi tersebut dapat dicapai melalui pembelajaran dengan pendekatan keterampilan proses SAINS. Keterampilan Proses SAINS tersebut adalah (1) melakukan observasi, (2) mengemukakan hipotesis, (3) menginterprestasi, (4) merancang percobaan, (5) melakukan investigasi, (6) menarik kesimpulan, dan (7) mengkomunikasikan hasil (Semiawan dkk dalam Samatowa, 2011).

E-learning merupakan media elektronik yang diciptakan untuk pembelajaran daring dengan tujuan mengefektifkan proses belajar mengajar apabila guru/dosen tidak dapat tatapmuka langsung dengan peserta didik. Interaksi antara tenaga pendidik dan peserta didik dapat dilakukan dengan tatap muka langsung atau dapat menggunakan media elektronik sebagai perantara suasana belajar sehingga suasana belajar menadi lebih menarik, visual, dan interaktif (Tasiman dkk, 2014). Kemajuan teknologi mendorong upaya keterbaruan pemanfaatannya dalam proses belajar mengajar (Sugianto etal, 2018). Pembelajaran berbantukan e-learning diharapkan dapat memberikan pengaruh yang positif dan meningkatkan kreativitas serta kemandirian mahasiswa dalam proses belajar. Pada penelitian ini $e$ learning yang digunakan adalah edmodo. Pemilihan edmodo sesuai dengan hasil survey yang dilakukan sebelum melakukan penelitian. Mahasiswa lebih memilih edmodo karena tiga hal, yang pertama edmodo memiliki fitur yang sederhana namun sudah mencangkup kebutuhan dalam melakukan pembelajaran. Kedua, edmodo lebih mudah digunakan dan tidak rumit dalam pemakaiannya. Ketiga, edmodo memiliki kapasitas sedikit dalam mengambil ruang memori dan lebih hemat dalam pemakaian kuota. Dari hal tersebut menyatakan bahwa edmodo lebih unggu daripada aplikasi lainnya dan menjadi pilihan mahasiswa.

Keempat latar belakang permasalahan tersebut menjadikan titik acuan untuk meningkatkan kreativitas mahasiswa pendidikan fisika di Unindra dengan penerapan pembelajaran berbasis proyek dengan e-lerning untuk meningkatkan kreativitas dan hasil belajar mahasiswa pada mata kuliah IPA Terpadu. Rumusan masalah pada penelitian ini adalah 1) adakah peningkatan penerapan pembelajaran berbasis proyek dengan menggunakan e-learning terhadap kreativitas mahasiswa? 2) adakah pengaruh pembelajaran berbasis proyek dengan menggunakan e-learning terhadap hasil belajar mahasiswa? Tujuan dari penelitian ini adalah 1) untuk mengetahui ada tidaknya peningkatan penerapan pembelajaran berbasis proyek dengan menggunakan e-learning terhadap kreativitas mahasiswa. 2) untuk mengetahui ada tidaknya pengaruh pembelajaran berbasis proyek dengan menggunakan e-learning terhadap hasil belajar mahasiswa.

\section{METODE PENELITIAN}

Penelitain ini dilakukan di Universitas Indraprasta PGRI tahun ajaran 2019/2020 semester ganjil dengan mata kuliah IPA Terpadu. Metode yang digunakan dalam penelitian ini pre-post experimental desain dengan jenis one group pretest-posttest yang meneliti tentang penerapan pembelajaran berbasis proyek dengan e-lerning untuk meningkatkan kreativitas dan hasil belajar mahasiswa pada mata kuliah IPA Terpadu. Subjek dalam penelitian ini adalah semester 7 dengan jumlah 35 mahasiswa.

Pada penelitian ini pengumpulan data menggunakan tiga metode yaitu , pertama observasi yang bertujuan untuk mengumpulkan data penelitian dengan menggunakan lembar observasi yang dikembangkan peneliti. Kreativitas diukur menggunakan angket kreativitas terdiri dari 20 butir. Hasil belajar kognitif menggunakan soal pretest dan posttest dengan soal esai sebanyak 15 butir soal yang diperoleh kemudian dianalisis menggunakan teknil analisis deskripstif kuantitatif berupa uji t dan uji $n$ gain. Analisis deskriptif yang terdapat pada lembar angket akan dianalisis kuantitatif berupa uji t dan uji $n$ gain pada rata-rata hasil krativitas dan kognitif mahasiswa. 


\section{HASIL DAN PEMBAHASAN}

Pada penelitian ini mahasiswa diberikan tugas proyek yaitu membuat komik digital IPA terpadu secara berkelompok. Mahasiswa diberi waktu 3 minggu untuk menyelesaikan tugas tersebut dengan tiga tahapan yaitu pertama, penyusunan story board, kedua penyusunan komik, ketiga finising dengan memperbaiki bagian-bagian desain serta kesusuaian materi dan gambar. Pembuatan komik tersebut dapat menjadi tolak ukur kreativitas mahasiswa. Pembuatan komik dilakukan dengan beberapa tahapan yang pertama adalah menentukan tema pada komik IPA Terpadu yang akan dibuat. Kedua, penyusunan story board yang bertujuan untuk memudahkan dalam penyusunan komik. Ketiga, memilih aplikasi digital yang akan dibuat dalam pembuatan komik sesuai yang dibutuhkan.

Data kreativitas mahasiswa diperoleh dari angket yang dikembangkan oleh peneliti dari aspekaspek kreativitas. Angket kreativitas yang terdiri dari 20 butir yang dirangkum pada tabel 1 .

Tabel 1. Angket Kreativitas Mahasiswa

1. Jika materi yang diajarkan belum paham, saya selalu bertanya pada

SR $\quad$ SL $\quad$ K $\quad$ TP
dosen

2. Untuk memuaskan rasa ingin tahu terhadap suatu materi kuliah, saya juga banyak membaca buku di perpustakaan

3. Ketika ada suatu hal yang menarik dan berhubungan dengan materi yang diternagkan, saya menanyakan kepada dosen.

4. Kerja kelompok meruupakan hal yang menyenangkan, karena saya dapat menyumbangan banyak ide dalam kerja kelompok

5. Jika dosen mempersilahkan untuk berpendapat, maka saya menyampaikan pendapat sesuai kemampuan saya

6. Saya membuat model alat baru dalam kerja kelompok untuk memudahkan menjelaskan kepada teman-teman dan dosen

7. ika tidak bisa membeli suatu media pembelajaran, saya membuat model yang sama dengan lebih sederhana

8. Dosen meminta untuk melakukan kerja ilmiah, saya memodifikasi cara yang ada untukmenjelaskannya

9. Saya selalu memakai pakaian rapi saat kuliah

10. Jika suatu cara tidak dapat menyelesaikan suatu masalah, saya akan mencari cara lain.

11. Jika teman meminta bantuan mecarikan pemecahan suatu masalah, saya akan mencari pemecahan semampunya.

12. Jika mendapat tugas kelompok, saya selalu mengerjakan sendiri

13. Jika buku penunjang kuliah mahal, saya akan meminjam teman dan merangkumnya.

14. Jika ada tugas kelompok yang harus dikumpulkan, maka saya akan mengumpulkan tepat waktu

15. ika ada materi yang belum mengerti, saya selalu meminta dosen untuk mengulanginya lagi

16. Selain pada dosen, saya juga memuaskan rasa ingin tahu saya terhadap materi kuliah kepada keluarga dirumah

17. Jika ada lomba karya ilmiah mahasiswa saya akan membuat alat yang belum pernah dibuat mahasiswa lainnya

18. Saya selalu mengikuti kegiatan yang dapat meningkatkan kemampuan saya

19. Saya suka membaca cerita-cerita lucu

20. Saya suka dosen yang menyampaikan materi dengan ringan, lucu, dan padat.

Angket kreativitas memiliki empat pilihan selalu (S), sering (SR), kadang (K), dan tidak pernah (TP). Data hasil kreativitas mahasiswa yang terdiri dari 20 butir yang dikembangkan oleh peneliti dari aspek kreativitas memberikan hasil data pretest dan posttest diperoleh data pada tabel 2.

Tabel 2 Hasil Angket Kreativitas

\begin{tabular}{lll}
\hline Angket Kreativitas & Pretest & Posttest \\
\hline Skor terendah & 45 & 68 \\
\hline Skor tertinggi & 68 & 80 \\
\hline Rata-rata & 58 & 75 \\
\hline
\end{tabular}


Hasil data Kreativitas yang diperoleh dari angket kreativitas yang diberikan pada mahasiswa memperoleh hasil pretest mendapat skor terendah 45 dan pada posttest medapat skor terendah 68, sehingga dapat disimpulkan terdapat kenaikan skor pada skor terendah. Pada skor tertinggi saat pretest diperoleh hasil 68 dan posttest 80 dan disimpulkan terdapat kenaikan skor tertinggi. Rata-rata hasil pretest diperoleh 58 dan posttest 75 , sehingga pembelajaran menggunakan proyek memberikan pengaruh yang signifikan terhadap kreativitas mahasiswa. Wismanto (2018) menyatakan bahwa pembelajaran menggunakan Quantum teaching memberikan pengaruh terhadap kreativitas siswa.

Hasil belajar yang diteliti adalah hasil belajar kognitif yang diperoleh dari soal posttest dan pretest yang diberikan pada mahasiswa. Data hasil belajar disajikan pada tabel 3.

Tabel 3. Hasil belajar kognitif

\begin{tabular}{lll}
\hline Hasil Belajar Kognitif & Pretest & Posttest \\
\hline Skor terendah & 55 & 70 \\
\hline Skor tertinggi & 75 & 87 \\
\hline Rata-rata & 63 & 79 \\
\hline
\end{tabular}

Hasil data hasil belajar kognitif yang diperoleh dari soal tes yang diberikan pada mahasiswa memperoleh hasil pretest mendapat skor terendah 55 dan pada posttest medapat skor terendah 70 , sehingga dapat disimpulkan terdapat kenaikan skor pada skor terendah. Pada skor tertinggi saat pretest diperoleh hasil 75 dan posttest 87 dan disimpulkan terdapat kenaikan skor tertinggi. Rata-rata hasil pretest diperoleh 63 dan posttest 79, sehingga pembelajaran menggunakan proyek memberikan pengaruh yang signifikan terhadap hasil belajar mahasiswa. Penelitian ini memliki hasil yang sesuai dengan penelitian yang dilakukan Nai'mah dkk (2015) yang menyatakan bahwa pembelajaran berbasis proyek dapat mempengaruhi hasil belajar. Pada dasarnya, pembelajaran berbasis proyek merupakan model pembelajaran yang menuntut mahasiswa untuk berpartisipasi secara aktif baik secara individu maupun berkelompok melalui kerjasama sehingga melibatkan mahasiswa dalam investigasi pemecahan masalah. Melalui pembelajaran berbasis proyek, selain hasil belajar pada ranah kognitif, kemampuan lain siswa seperti kreativitas dan motivasi belajar dapat meningkat (Pradita et al., 2015).

Hal ini yang menjadi landasan dari aspek penilaian ranah psikomotorik selama proses pembelajaran berlangsung menunjukkan bahwa mahasiswa mampu melaksanakan setiap tahapan proyek dengan baik sesuai dengan kriteria penilaian yang sudah ditetapkan. Selain itu, hasil belajar mahasiswa pada ranah afektif menyimpulkan bahwa dari setiap aspek pengamatan ternyata memiliki kriteria yang baik pada kebanyakan mahasiswa yang belajar dengan penerapan pembelajaran berbasis proyek. Dalam pelaksanaannya, model pembelajaran berbasis proyek dilakukan dengan metode percobaan berupa proyek, demonstrasi, diskusi dan tanya jawab serta ceramah. Dengan model pembelajaran berbasis proyek yang diterapkan melalui metode proyek mampu menjadikan mahasiswa lebih kreatif dan inovatif, berfikir kritis, serta mengaplikasikan materi yang didapatkan dalam kehidupan sehari-hari.

\section{PENUTUP}

Simpulan pada penelitian ini adalah dengan menggunakan model pembelajaran proyek dapat meningkatkan hasil belajar kognitif mahasiswa. Melalui model pembelajaran proyek menggunakan elearning juga memberikan pengaruh yang signifikan terhadap kreativitas mahasiswa.

Saran untuk peneliti selanjutnya dapat menggunakan mata kuliah lainnya dan dimodifikasi sesuai kebutuhan mahasiswa. Pembelajaran ini juga bisa diterapkan pada tingkatan sekolah untuk para guru.

\section{DAFTAR PUSTAKA}

Al-Tabany, I. B. Trianto. 2014. Mendesain Model Pembelajaran Inovatif, Progresif, dan Kontekstual.

Hayati, M. N., Supardi, K. I., \& Miswadi, S. S. (2013). Pengembangan pembelajaran IPA SMK dengan model kontekstual berbasis proyek untuk meningkatkan hasil belajar dan keterampilan proses sains siswa. Jurnal Pendidikan IPA Indonesia, 2(1).

Na'imah, N. J. Supartono, \& S. Wardani. 2015. Penerapan Pembelajaran Berbasis Proyek Berbantuan. ELearning, 1566-1574. 
Rumahorbo, D. N. (2017). PENGEMBANGAN BAHAN AJAR BERBASIS PROYEK UNTUK MATERI ALDEHIDA DAN KETON DI SEKOLAH MENGENGAH ATAS(Doctoral dissertation, UNIMED).

Samatowa, U. (2011). Pembelajaran IPA di sekolah dasar.

Sugianto, S. D., Ahied, M., Hadi, W. P., \& Wulandari, A. Y. R. (2018). Pengembangan Modul IPA Berbasis Proyek Terintegrasi STEM pada Materi Tekanan. Natural Science Education Research, 1(1), 28-39.

Tasiwan, T., Nugroho, S. E., \& Hartono, H. (2014). Analisis Tingkat Motivasi Siswa dalam Pembelajaran IPA Model Advance Organizer Berbasis Proyek. Jurnal Pendidikan IPA Indonesia, 3(1).

Wismanto, W. (2018). PENGARUH PENERAPAN MODEL QUANTUM TEACHING TERHADAP KREATIVITAS SISWA DALAM PEMBELAJARAN IPA. BASIC EDUCATION, 7(8), 795806. 